\title{
DAZAP1 wt Allele
}

National Cancer Institute

\section{Source}

National Cancer Institute. DAZAP1 wt Allele. NCI Thesaurus. Code C92146.

Human DAZAP1 wild-type allele is located in the vicinity of 19p13.3 and is approximately $28 \mathrm{~kb}$ in length. This allele, which encodes DAZ-associated protein 1, may be involved in spermatogenesis and RNA binding. A translocation, $\mathrm{t}(1 ; 19)(\mathrm{q} 23 ; \mathrm{p} 13.3)$ involving this gene and the MEF2D gene, creates reciprocal DAZAP1/MEF2D and MEF2D/DAZAP1 fusion genes and both transcripts are expressed as fusion proteins in acute lymphoblastic leukemia. 